\title{
PENICILLINASE PRODUCTION AND INTRINSIC RESIST- ANCE TO PENICILLINS IN METHICILLIN-RESISTANT CULTURES OF STAPHYLOCOCCUS AUREUS
}

\author{
K. G. H. DYKE* \\ Medical Research Council Staff, Cross-Infection Laboratory, Central \\ Public Health Laboratory, Colindale Avenue, Colindale, London
}

Methicillin is relatively insusceptible to the action of staphylococcal penicillinase, but naturally occurring strains of Staphylococcus aureus that are resistant to methicillin usually produce large quantities of the enzyme. Staphylococcal penicillinase does hydrolyse methicillin slowly (Novick, 1962), and it therefore seemed possible that methicillin resistance might be due in part to the inactivation of methicillin. Stewart and Holt (1963) and Eriksen and Erichsen (1964) reported that methicillin-resistant strains were capable of a greater inactivation of methicillin than were methicillin-sensitive strains, but Richmond et al. (1964) found no difference between the average amount of penicillinase produced by methicillin-resistant staphylococci and by other multiple-antibiotic resistant but methicillin-sensitive " hospital" staphylococci.

Penicillinase could play only a minor role in the resistance to methicillin of the cultures examined by Baudens, Gerbaud and Chabbert (1965), by Dyke, Jevons and Parker (1966) and by Seligman (1966a), since variants that had lost the ability to synthesise penicillinase showed levels of resistance to methicillin similar to those of the parent strains. It appears, therefore, that they are organisms with an intrinsic insusceptibility to the action of methicillin, and indeed to all penicillins, and that their possession of an active penicillinase, like their resistance to other unrelated antibiotics, is an incidental character.

Although the ability to inactivate methicillin is apparently not of major importance in the mechanism of methicillin resistance in strains that have so far been examined, it seemed possible that a single mutation in the structural gene for penicillinase might lead to the synthesis of a protein with an increased ability to hydrolyse methicillin. I therefore undertook a prospective survey of the properties of the penicillinase produced by large numbers of methicillinresistant strains of $S$. aureus to discover any evidence for the appearance of such a specific " methicillinase" (Pollock, 1962).

Methicillin-resistant cultures of $S$. aureus are characteristically heterogeneous as regards the resistance of individual cells of a culture (Knox, 1961; Rolinson, 1961; Chabbert and Baudens, 1962). The distribution of the resistance of the cells within a culture has been studied in detail by Sutherland and Rolinson (1964), who found that only a minority of the population was resistant and that, on subculture of a clone from the resistant minority in the absence of methicillin, the distribution of resistance within the population rapidly became the same as in the original culture. Seligman (1966b) confirmed these results and suggested

Received 22 Nov. 1968; accepted 17 Dec. 1968.

* Present address: Department of Biochemistry, South Parks Road, Oxford. 
that there was a single-step increase in resistance, but his results appear to be more consistent with the hypothesis that resistance to methicillin is determined by a polygenic system.

Little is known about the genetic factors that control resistance to methicillin, or about the biochemical basis of the insusceptibility of resistant organisms to the action of methicillin and other penicillins. This paper reports the results of a number of investigations of various aspects of the problem.

\section{MATERIALS AND METHODS}

Media. Cultures were grown in the 1 per cent. casein hydrolysate medium (CY) of Novick (1963). When appropriate, this medium was solidified by addition of 1.5 per cent. (w/v) Difco-Bacto Agar.

Organisms. The strain used as a standard for penicillinase production is no. 524SC (Rogers, 1953). No. 13136 is the methicillin-resistant culture described by Jevons (1961). The Oxford staphylococcus is NCTC no. 6571. Most of the methicillin-resistant S. aureus cultures examined had been selected from strains submitted to the Cross-Infection Laboratory, Colindale, for phage typing, and the rest were cultures sent to the laboratory as methicillinresistant staphylococci. No. 9204 (see Dyke et al.) is a methicillin-resistant strain that has never been shown to produce penicillinase. Penicillinase-negative variants of two of the strains were used in some experiments, and are referred to by the culture number followed by the letter $\mathbf{N}$.

Antiserum. An antiserum prepared in rabbits with purified A-type staphylococcal penicillinase (Richmond, 1965) was the gift of Dr M. H. Richmond.

Determination of resistance to methicillin. Cultures were initially considered to be resistant to methicillin if they showed a narrowing of the zone of inhibition around a $10 \mu \mathrm{g}$ methicillin disc and if the minimum inhibitory concentration (MIC) was $\geqq 12.5 \mu$ g methicillin per $\mathrm{ml}$ in a tube dilution test incubated at $37^{\circ} \mathrm{C}$ for $18 \mathrm{hr}$ (Parker and Jevons, 1964). In this paper, resistance was measured either by a plate dilution test in which $0.02-\mathrm{ml}$ drops of a 6-hr broth culture were placed on the surface of CY-agar plates containing different concentrations of methicillin, or by a tube dilution test. In the latter, $10^{6}$ organisms were added to tubes of medium containing various concentrations of the antibiotic; the presence or absence of growth was recorded after 48 hours' incubation at $37^{\circ} \mathrm{C}$. The 48 -hr incubation permitted the resistant minority to grow to a noticeable density (Sutherland and Rolinson).

Induction and estimation of penicillinase. Penicillinase was estimated by the method of Novick (1962), which is a modification of the iodometric assay of Perret (1954). The amount of penicillinase produced by the cultures was determined after induction under standard conditions (Richmond et al.), and the amount was related by a ratio to the quantity produced by no. 524SC under similar conditions. A portion of the fully induced culture was centrifuged at $2500 \mathrm{~g}$ for $10 \mathrm{~min}$. and the amount of penicillinase in the supernatant fluid was estimated. The sedimented cells were washed once in $0 \cdot 1 \mathrm{M}$ phosphate buffer $p \mathbf{H} 7 \cdot 0$ and resuspended in the same buffer. This cell preparation was used in some experiments on methicillin hydrolysis.

Hydrolysis of methicillin. The hydrolysis of methicillin was measured in $0 \cdot 1 \mathrm{M}-\mathrm{Na}_{2} \mathrm{HPO}_{4-}$ $\mathrm{KH}_{2} \mathrm{PO}_{4}$ buffer, $p \mathrm{H} 7.0$ at $35^{\circ} \mathrm{C}$ with a substrate concentration of $16 \mathrm{~mm}$ in the presence of $1 \cdot 5 \mathrm{M}-\mathrm{NaCl}$ to reduce inactivation (Dyke, 1967). Supernatant fluid containing penicillinase at a final concentration of 100 units per $\mathrm{ml}$ was added, and $5.0 \mathrm{ml}$ samples were pipetted into $10.0 \mathrm{ml}$ of $0.016 \mathrm{M}$-iodine $+0.006 \mathrm{M}$-potassium iodide in $2 \mathrm{M}$ acetate buffer, $p \mathrm{H} 4.2$. This mixture was allowed to react for $10 \mathrm{~min}$. at room temperature and then titrated with sodium thiosulphate. By this method, the quantity of methicilloic acid formed was estimated iodometrically and compared with that formed by the penicillinase of no. 524SC under the same conditions.

Selection of penicillinase-negative variants. These were selected from strains no. 524SC and no. 13136 as previously described (Dyke et al.).

Treatment with ethylmethane sulphonate. The procedure of Novick (1963) was followed. 
Transduction. Bacteriophage 53 of the basic typing set was propagated in lytic cycle on the donor strain of staphylococcus by the method of Swanstrom and Adams (1951). The phage preparation was filtered to remove any remaining bacteria and then mixed with the recipient bacteria suspended in CY medium with $0.002 \mathrm{M}-\mathrm{CaCl}_{2}$. The mixture was incubated for $30 \mathrm{~min}$. at $35^{\circ} \mathrm{C}$ and further adsorption of phage was then prevented by the addition of sodium citrate to a final concentration of $0 \cdot 1 \mathrm{M}$. The cells were sedimented at $2500 \mathrm{~g}$ for $10 \mathrm{~min}$., resuspended in $\mathrm{CY}$ medium with added $0.1 \mathrm{M}$ sodium citrate, and incubated at $35^{\circ} \mathrm{C}$ for a time that varied for different experiments.

Isolation of mucopeptide. The method was based on that of Park and Hancock (1960). Cultures were incubated with shaking until they contained $2 \cdot 0 \pm 0 \cdot 2 \mathrm{mg}$ of bacterial dry wt per $\mathrm{ml}$, and were harvested. The deposit was washed once in $0.1 \mathrm{M}$ phosphate buffer, $p \mathrm{H} 7 \cdot 0$, and resuspended in 5 per cent. $\mathrm{w} / \mathrm{v}$ trichloroacetic acid. It was then heated at $90^{\circ} \mathrm{C}$ for $8 \mathrm{~min}$., cooled and centrifuged at $2500 \mathrm{~g}$ for $10 \mathrm{~min}$. The residue was washed twice in $0.05 \mathrm{M}$ $\mathrm{NH}_{4} \mathrm{HCO}_{3}$, resuspended in $5.0 \mathrm{ml} 0.05 \mathrm{M}-\mathrm{NH}_{4} \mathrm{HCO}_{3}+0.005 \mathrm{~N}-\mathrm{NH}_{4} \mathrm{OH}$ containing $0.2 \mathrm{mg}$ trypsin, and incubated for $16 \mathrm{hr}$ at $37^{\circ} \mathrm{C}$. The incubation mixture was washed three times in water and then dried, first in a desiccator and subsequently to constant weight in an oven at $95^{\circ} \mathrm{C}$.

Estimation of the amino acid composition of the mucopeptide. The method of Mandelstam and Rogers (1959) was followed, except that glutamic acid and lysine were not estimated separately.

Estimation of glucosamine and muramic acid. Glucosamine and muramic acid were determined as described by Perkins and Rogers (1959).

\section{RESUlTS}

\section{Sources of strains}

A total of 72,310 cultures received by the Cross-Infection Laboratory, Colindale, for phage-typing in the years 1960-66 were tested for methicillin resistance (see Jevons; Jevons, Coe and Parker, 1963; Dyke et al.) and 516 of them $(0.71$ per cent.) were found to be resistant (table I). Staphylococci sent to the laboratory because they were methicillin-resistant and duplicate isolates of resistant strains from the same patient were excluded. Cultures were considered to represent epidemiologically distinct strains when they had been isolated in separate hospitals, or if they differed in phage-typing pattern from other resistant cultures from the same hospital. Among the 516 resistant cultures from the survey there were representatives of 85 distinct strains, and a further 23 distinct strains were obtained from among the cultures sent to the laboratory as methicillin-resistant staphylococci. The sources of the 108 distinct strains were as follows: 92 from 55 British hospitals, 10 from 5 European hospitals and 6 from 4 African hospitals.

In all, 343 cultures of methicillin-resistant $S$. aureus were examined for hydrolysis of methicillin, and these included representatives of every one of the 108 distinct strains.

\section{Penicillinase of methicillin-resistant cultures}

Quantitative estimation of the amount of penicillinase produced under standard conditions indicated that all but one of the 343 cultures produced large amounts of penicillinase, but that the amount did not exceed one and a half times that produced by the standard strain for any of the cultures. The remaining culture produced no detectable penicillinase (Dyke et al.). In all 
342 cultures, approximately 40 per cent. ( \pm 15 per cent.) of the penicillinase was extracellular under the conditions of induction used. Penicillinase produced by all 27 of the strains tested was stimulated at least three-fold by specific antiserum and was therefore immunologically A-type enzyme (Richmond).

A-type staphylococcal penicillinase does show some ability to hydrolyse methicillin. The relevant constants are a Michaelis constant $\left(\mathrm{K}_{\mathrm{m}}\right)$ of $24 \mathrm{~mm}$ and a maximal rate of hydrolysis $\left(\mathrm{V}_{\max }\right)$ of $1.54 \mu$ moles of methicillin hydrolysed per hr per 50 units of benzylpenicillinase at $p \mathrm{H} 7.0$ and $35^{\circ} \mathrm{C}$ (Dyke). The

TABLE I

Survey of methicillin resistance

\begin{tabular}{|c|c|c|c|c|c|}
\hline \multirow[b]{2}{*}{ Years } & \multicolumn{5}{|c|}{ Number of } \\
\hline & $\begin{array}{l}\text { cultures } \\
\text { tested }\end{array}$ & $\begin{array}{c}\text { cultures } \\
\text { resistant } \\
\text { to } \\
\text { methicillin }\end{array}$ & $\begin{array}{l}\text { epidemiologically } \\
\text { distinct } \\
\text { strains isolated }\end{array}$ & $\begin{array}{l}\text { other } \\
\text { epidemiologically } \\
\text { distinct strains } \\
\text { submitted as } \\
\text { methicillin-resistant }\end{array}$ & $\begin{array}{l}\text { cultures tested } \\
\text { for hydrolysis } \\
\text { of methicillin }\end{array}$ \\
\hline $\begin{array}{l}1960 \\
1961 \\
1962 \\
1963 \\
1964 \\
1965 \\
1966\end{array}$ & $\begin{array}{r}5440 \\
12,952 \\
11,886 \\
11,110 \\
9978 \\
8999 \\
11,945\end{array}$ & $\begin{array}{r}3 \\
47 \\
75 \\
74 \\
97 \\
74 \\
146\end{array}$ & $\begin{array}{r}1 \\
9 \\
11 \\
7 \\
20 \\
23 \\
14\end{array}$ & $\begin{array}{l}0 \\
0 \\
0 \\
0 \\
9 \\
9 \\
5\end{array}$ & $\begin{array}{r}3 \\
34 \\
29 \\
32 \\
106 \\
83 \\
56\end{array}$ \\
\hline $1960-66$ & 72,310 & 516 & 85 & 23 & 343 \\
\hline
\end{tabular}

This table is based in part on information kindly provided by Dr M. T. Parker and his colleagues in this Laboratory.

enzyme would be an "improved" methicillinase either if the $\mathrm{K}_{\mathrm{m}}$ were reduced or if the $\mathrm{V}_{\max }$ were increased. Ideally, to detect such a change it would be necessary to determine the $\mathrm{K}_{\mathrm{m}}$ and $\mathrm{V}_{\max }$ for the enzyme produced by each culture, but we expected to detect any major change in either parameter by measuring the rate of hydrolysis of methicillin at a concentration (16 mM) lower than the $\mathrm{K}_{\mathrm{m}}$.

All 343 of the cultures were tested for hydrolysis of methicillin, but to avoid duplication only the results for the 107 epidemiologically distinct penicillinaseproducing strains are shown in fig. 1 . Nearly 50 per cent. of the penicillinases hydrolyse methicillin at a rate indistinguishable from that of 524SC. The four cultures that on initial investigation were shown to hydrolyse methicillin at greater than 120 per cent. of the standard rate were re-tested and found to be less than 5 per cent. different from the standard. Therefore, in none of the cultures is there any evidence for the production of an "improved" enzyme. Hydrolysis of methicillin by cell-bound penicillinase of 37 of the cultures was not greater than hydrolysis by cell-bound penicillinase of 524SC. 
A culture of the methicillin-sensitive strain no. 524SC was treated with ethylmethane sulphonate to give $0 \cdot 1$ per cent. survivors and after growth for $3 \frac{1}{2} \mathrm{hr}$ in the absence of methicillin, $10^{7}$ cells were spread on each of 10 petri dishes containing CY-agar with added methicillin $(10 \mu \mathrm{g}$ per $\mathrm{ml}$.). After 48 hours' incubation at $37^{\circ} \mathrm{C} 27$ colonies had grown and these were cultured and tested for methicillinase. In no case was a colony with increased ability to hydrolyse methicillin discovered.

Since only a small minority of a culture of methicillin-resistant organisms is highly resistant, it might be that this small minority produces an altered

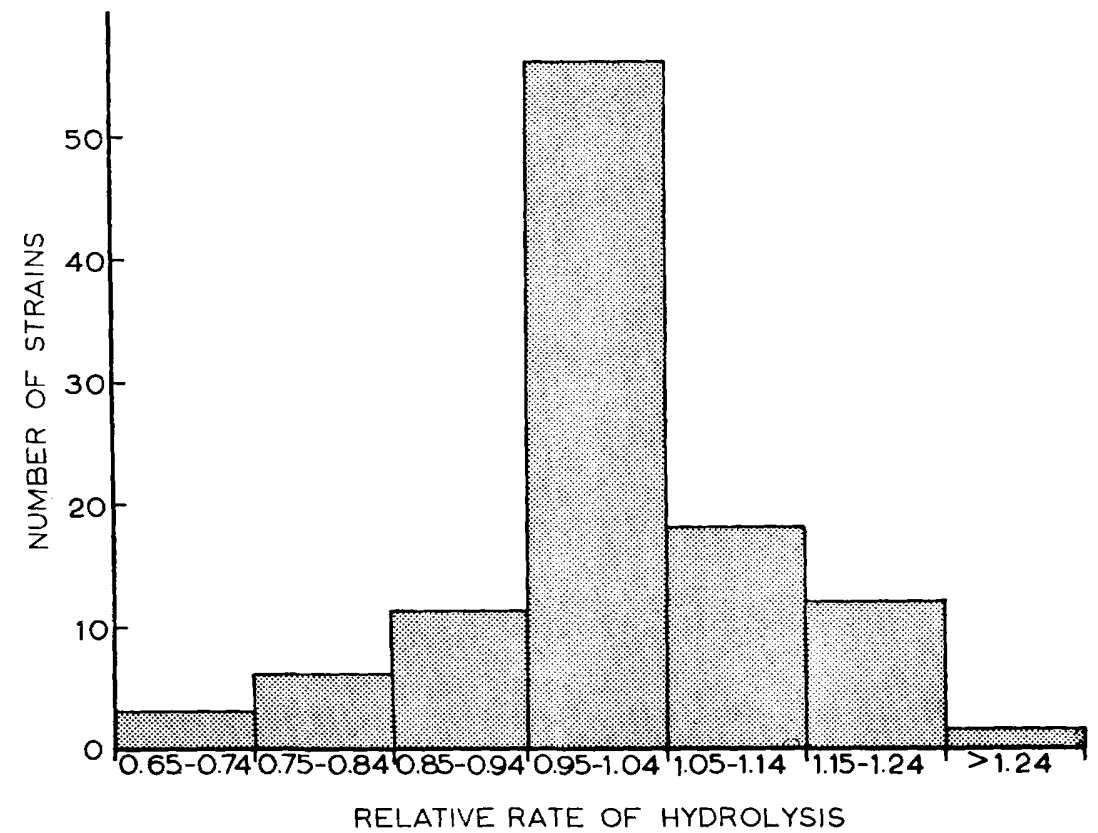

FIG. 1.-Rate of hydrolysis of $16 \mathrm{~mm}$ methicillin at $p \mathrm{H} 7.0$ and $35^{\circ} \mathrm{C}$ by penicillinase (100 units per $\mathrm{ml}$ ) produced by epidemiologically distinct methicillin-resistant strains of Staphylococcus aureus relative to the rate of hydrolys is by penicillinase produced by no. 524SC.

penicillinase. Testing of the penicillinase produced by a colony of no. 13136 selected from a plate containing $500 \mu \mathrm{g}$ methicillin per $\mathrm{ml}$ showed that the penicillinase was no different from that produced by the remainder of the original population.

There is no evidence that an " improved " methicillinase has evolved among naturally occurring strains of " hospital " staphylococci or that such an altered enzyme can be readily produced subsequent to reaction with a mutagen.

\section{Heterogeneity of methicillin-resistant cultures}

In order that the slight hydrolysis of methicillin by penicillinase should not obscure the results, a penicillinase-negative variant (no. 13136N) of strain no. 13136 was selected and used to study intrinsic resistance to methicillin. A late exponential phase culture of no. $13136 \mathrm{~N}$ was diluted in CY-medium in a 
series of ten-fold steps and then $0.02-\mathrm{ml}$ drops were placed on the surface of CY-agar containing different concentrations of methicillin. The plates were incubated at $37^{\circ} \mathrm{C}$ for $48 \mathrm{hr}$, and then the number of colonies formed was counted. The results of such an experiment are shown in table II. All the organisms were capable of producing colonies on $5 \mu \mathrm{g}$ methicillin per $\mathrm{ml}$ and over 10 per cent. formed colonies on $10 \mu \mathrm{g}$ methicillin per ml. Five of the original $3.5 \times 10^{9}$ organisms were able to form colonies even in the presence of $640 \mu \mathrm{g}$ methicillin per $\mathrm{ml}$. The heterogeneous nature of this resistance is shown

TABLE II

Number of colonies of a penicillinase-negative variant of a methicillin-resistant strain (no. $13136 N$ ) that grow on agar containing various methicillin concentrations

\begin{tabular}{|c|c|c|c|c|c|c|c|c|}
\hline \multirow{3}{*}{$\begin{array}{l}\text { Methicillin } \\
\text { concentration } \\
(\mu \mathrm{g} \text { per } \mathrm{ml})\end{array}$} & \multicolumn{8}{|c|}{$\begin{array}{l}\text { Colony growth, on agar containing this concentration of methicillin, } \\
\text { of } 0.02 \mathrm{ml} \text { culture }\end{array}$} \\
\hline & \multirow{2}{*}{ undiluted } & \multicolumn{7}{|c|}{ diluted } \\
\hline & & $10^{-1}$ & $10^{-2}$ & $10^{-3}$ & $10^{-4}$ & $10^{-5}$ & $10^{-6}$ & $10^{-7}$ \\
\hline $\begin{array}{c}\text { None } \\
5 \\
10 \\
20 \\
40 \\
80 \\
160 \\
320 \\
640\end{array}$ & $\begin{array}{l}C^{*} \\
C \\
C \\
C \\
C \\
C \\
C \\
C \\
C \\
5\end{array}$ & $\begin{array}{r}C \\
C \\
C \\
C \\
C \\
C \\
S C \\
10 \\
2\end{array}$ & $\begin{array}{r}C \\
C \\
\text { SC } \\
\text { SC } \\
\text { SC } \\
\text { SC } \\
36 \\
3 \\
0\end{array}$ & $\begin{array}{r}\mathrm{C} \\
\mathrm{C} \\
\mathrm{SC} \\
32 \\
25 \\
18 \\
4 \\
0 \\
0\end{array}$ & $\begin{array}{r}\mathrm{C} \\
\mathrm{C} \\
61 \\
13 \\
2 \\
1 \\
0 \\
0 \\
0 \\
0\end{array}$ & $\begin{array}{r}\mathrm{SC} \\
\mathrm{SC} \\
10 \\
2 \\
0 \\
0 \\
0 \\
0 \\
0\end{array}$ & $\begin{array}{r}57 \\
61 \\
8 \\
0 \\
0 \\
0 \\
0 \\
0 \\
0\end{array}$ & $\begin{array}{l}7 \\
7 \\
0 \\
0 \\
0 \\
0 \\
0 \\
0 \\
0\end{array}$ \\
\hline
\end{tabular}

* $\mathrm{C}=$ Confluent growth; $\mathbf{S C}=$ numerous colonies; numbers $=$ number of colonies.

A drop $(0.02 \mathrm{ml})$ of the appropriate dilution of culture was placed on the surface of agar containing methicillin at the concentrations indicated. After $1 \mathrm{hr}$ at room temperature the plate was transferred to $37^{\circ} \mathrm{C}$ and incubated for $48 \mathrm{hr}$. Initial culture density: $3.5 \times 10^{9}$ organisms per ml.

by the progressive decrease in the number of cells giving rise to colonies as the concentration of the antibiotic is increased.

Colonies of no. $13136 \mathrm{~N}$ growing in high concentrations of methicillin are pleomorphic. They range in colour from deep orange to white, may be large or small, and may appear in $24 \mathrm{hr}$ or not until $96 \mathrm{hr}$. The properties of a culture capable of forming colonies at a particular concentration of methicillin vary from day to day despite all precautions to ensure reproducibility.

Another phenomenon evident when testing for methicillin-resistance by placing drops of culture on the surface of methicillin-containing agar is as follows: when 0.02-ml drops of culture were placed on a plate containing $320 \mu \mathrm{g}$ methicillin per $\mathrm{ml}$, an inoculum of $10^{7}$ organisms led to confluent growth over the whole area of the drop, but with $5 \times 10^{6}$ organisms there was a central area of confluent growth surrounded by a region with discrete colonies, and sometimes there was also a line of dense bacterial growth at the periphery of the area of the drop. When $10^{6}$ organisms obtained by dilution of the same 
culture in CY-medium, or $p \mathrm{H} \mathrm{7.0} \mathrm{phosphate} \mathrm{buffer,} \mathrm{or} \mathrm{the} \mathrm{supernatant} \mathrm{from} \mathrm{an}$ exponential-phase culture of the same organism were placed on the same agar plate, only 10 colonies developed. Even at lower methicillin concentrations, ten-fold dilution of the culture commonly did not lead to a ten-fold reduction in the number of colonies formed. It seems as if there is some co-operative effect of the neighbouring cells at some cell densities, particularly at the higher methicillin concentrations.

Strain no. 9204, a methicillin-resistant strain that produces no penicillinase, also exhibits heterogeneity when dilutions are plated on CY-agar containing various concentrations of methicillin. However, the majority of the population is more resistant than the majority of a culture of no. $13136 \mathrm{~N}$, so that heterogeneity is evident only at higher concentrations of methicillin. This result may explain the difference in MIC values for different methicillin-resistant strains. The highest concentration of methicillin at which all the cells of a culture produce a colony varies from strain to strain. For no. $13136 \mathrm{~N}$ this value is $5 \mu \mathrm{g}$ methicillin per ml, whereas for no. 9204 it is $20 \mu \mathrm{g}$ methicillin per ml.

In order to test whether or not the individual cells of the culture were each capable of giving rise to a heterogeneous population the following experiment was performed. Five colonies of no. $13136 \mathrm{~N}$ growing in the absence of methicillin were picked at random and emulsified in CY-medium; dilutions were placed on CY-agar containing different amounts of methicillin. The distribution of resistance to methicillin in each of the colonies was indistinguishable from that in the original culture. Since the majority of cells in a resistant culture are sensitive, the colony presumably started as a small number of sensitive cells, but cells with many different degrees of resistance arise during the growth of the colony. Even sensitive individuals in the culture have the potentiality to give rise to a heterogeneous population.

Colonies growing in high concentrations of methicillin, when emulsified, diluted and plated, were found to contain only cells resistant to a high concentration of methicillin, but the pattern of resistance reverted to that of the original culture after a series of subcultures in the absence of methicillin, as described by Sutherland and Rolinson. An attempt was made to measure the rate at which these highly resistant cultures reverted to the original population structure. A culture of no. $13136 \mathrm{~N}$ was spread on the surface of CY-agar containing $500 \mu \mathrm{g}$ methicillin per $\mathrm{ml}$, and the plate was incubated for $48 \mathrm{hr}$ at $37^{\circ} \mathrm{C}$. The resulting colonies differed in size and pigmentation; eight were selected as being representative of different colonial types, and each was emulsified in CY-medium. The number of colony-forming units was determined, together with the proportion able to form colonies on agar containing $500 \mu \mathrm{g}$ methicillin per ml. Each of the eight emulsified colonies was grown at $37^{\circ} \mathrm{C}$ for $24 \mathrm{hr}$, and then subcultured by adding $0.02 \mathrm{ml}$ of the culture to $10 \mathrm{ml}$ of fresh CY-medium and grown at $37^{\circ} \mathrm{C}$ for $24 \mathrm{hr}$. The subculture was repeated many times so that serial subcultures that had each been diluted by a known amount were available. The growth from each subculture was tested for the proportion of cells able to give rise to a colony on CY-agar containing $500 \mu \mathrm{g}$ methicillin per $\mathrm{ml}$ (table III). Seven of the eight colonies behaved similarly in 
that after approximately 50 generations, the resistant cultures had reverted to the same resistance pattern as the parent culture. One of the colonies (no. $13136 \mathrm{~N} / \mathrm{S}$ ) remained as resistant as when first isolated throughout subculture over 200 generations; the same number of cells in the culture were able to give rise to colonies on CY-agar containing $500 \mu \mathrm{g}$ methicillin per $\mathrm{ml}$ as on antibiotic-free CY-agar. This culture (no. $13136 \mathrm{~N} / \mathrm{S}$ ) formed small colonies even in the absence of methicillin, but was unaltered in phage-typing pattern and in pattern of resistance to antibiotics other than penicillin.

TABLE III

Reversion to sensitivity of highly resistant variants of a methicillin-resistant, penicillinasenegative variant of no. 13136 grown in $500 \mu \mathrm{g}$ methicillin per $\mathrm{ml}$. Highly resistant colonies are subcultured serially in antibiotic-free CY-medium

\begin{tabular}{c|c|c}
\hline & $\begin{array}{c}\text { Proportion of colony-forming units growing in } 500 \mu \mathrm{g} \\
\text { methicillin per ml in subcultures from }\end{array}$ \\
\cline { 2 - 3 } $\begin{array}{c}\text { Estimated number of } \\
\text { generations }\end{array}$ & $\begin{array}{c}7 \text { of the } 8 \text { original resistant } \\
\text { colonies }\end{array}$ & $\begin{array}{c}\text { ce remaining original } \\
\text { resistant colony } \\
\text { (per cent.) }\end{array}$ \\
\hline 16 & 100 per cent. & 100 \\
25 & 1 in $10^{2}$ & 100 \\
34 & 1 in $5 \times 10^{3}$ & 100 \\
43 & 1 in $2 \times 10^{5}$ & 100 \\
52 & 1 in $2 \times 10^{6}$ & 100 \\
61 & 1 in $10^{6}$ & 100 \\
\hline 88 & & \\
\hline
\end{tabular}

\section{Rate of growth in the absence of methicillin}

Seligman (1966b) states that highly methicillin-resistant organisms are characteristically slow-growing, and suggests that overgrowth by faster growing, relatively sensitive back-mutations may be responsible for the re-establishment of the original population structure in the antibiotic-free media. The rate of growth of highly resistant organisms in the presence and in the absence of methicillin was therefore investigated.

An appropriate dilution of a culture of no. $13136 \mathrm{~N}$ was spread on CY-agar containing $50 \mu \mathrm{g}$ methicillin per $\mathrm{ml}$ and a further dilution was spread on antibiotic-free CY-agar. After incubation at $37^{\circ} \mathrm{C}$ for $48 \mathrm{hr}$, colonies had appeared on both plates. Thirty colonies of various sizes and differing pigmentation were removed from the methicillin plate, emulsified in CY-medium and diluted to give an initial cell density of $0.01 \mathrm{mg}$ per $\mathrm{ml}$. As a control, 30 colonies were removed from the plate without methicillin, emulsified and diluted to $0.01 \mathrm{mg}$ bacteria dry wt per $\mathrm{ml}$. The sixty colonies were shaken at $37^{\circ} \mathrm{C}$ and the time taken to increase from $0.2 \mathrm{mg}$ per $\mathrm{ml}$ to $0.4 \mathrm{mg}$ per $\mathrm{ml}$ was recorded for each of the cultures (fig. 2). Under these conditions the colonies selected from the methicillin-containing plate do not grow more slowly than those from the control plate. 
The mutant no. $13136 \mathrm{~N} / \mathrm{S}$, which is homogeneously and stably resistant to high levels of methicillin, although it forms small colonies on antibiotic-free agar, grows as rapidly as no. $13136 \mathrm{~N}$ in CY liquid medium. During serial subculture of no. $13136 \mathrm{~N} / \mathrm{S}$ a large-colony-forming mutant no. $13136 \mathrm{~N} / \mathrm{S} / \mathrm{L}$ developed spontaneously; this formed colonies on CY-agar similar in size to those of no. $13136 \mathrm{~N}$, but nevertheless was as homogeneously resistant to higher concentrations of methicillin as no. $13136 \mathrm{~N} / \mathrm{S}$.
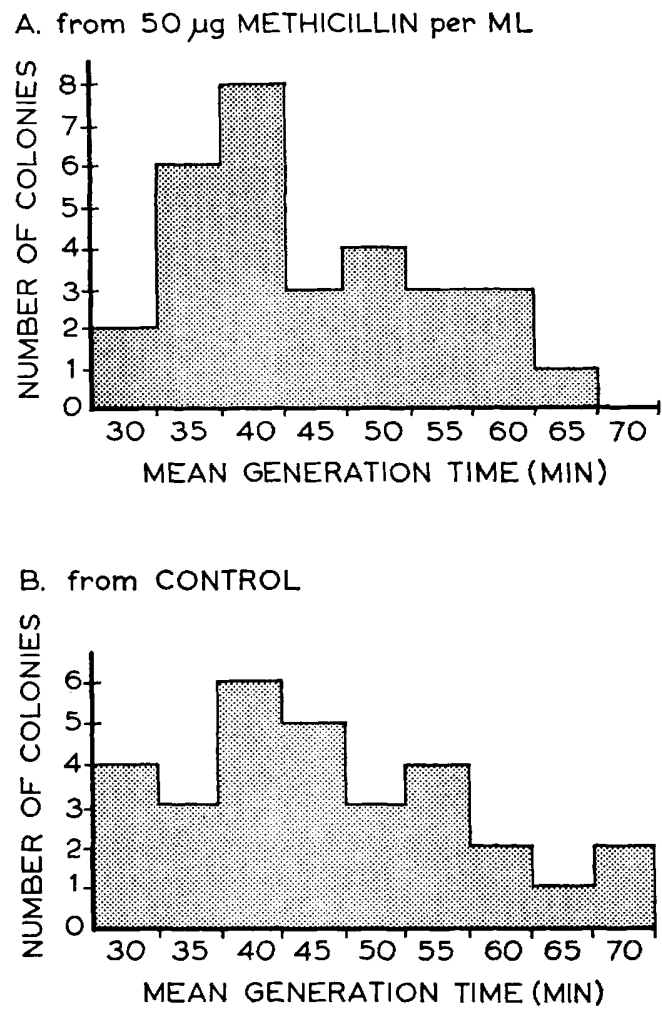

FIG. 2.-Rate of growth of clones of no. 13136N. Colonies were removed from the surface of $\mathrm{CY}$-agar containing either $50 \mu \mathrm{g}$ methicillin per $\mathrm{ml}$ or no methicillin and emulsified; the mean generation time was determined in $\mathrm{CY}$-medium at $37^{\circ} \mathrm{C}$.

Incubation of no. $13136 \mathrm{~N}$ with ethylmethane sulphonate followed by spreading on CY-agar gave rise to a few small colony variants. Four of these variants were tested and were of the same heterogeneous resistance to methicillin as the present culture.

Decrease of the rate of growth of no. $13136 \mathrm{~N}$ either by boric acid or by neomycin sulphate did not increase the resistance of the organism to methicillin.

\section{Attempts to transduce methicillin-resistance}

If resistance to methicillin is due to a mutation or to several closely linked mutations, it might be possible to transduce this character to a sensitive strain. 
Phage 53 was grown on no. $13136 \mathrm{~N}$ and mixed with the recipient $524 \mathrm{SC} \mathrm{N}$ at a multiplicity of infection of $0 \cdot 1$. After absorption of the phage for $30 \mathrm{~min}$. at $35^{\circ} \mathrm{C}$ and centrifugation followed by resuspension of the cells in CY-medium containing $0 \cdot 1 \mathrm{M}$ sodium citrate, the culture was divided into three parts which were treated in different ways.

(a) The first part was plated directly on CY-agar containing either 5 or $10 \mu \mathrm{g}$ methicillin per $\mathrm{ml}$.

TABLE

Effect of added 5 per cent. $\mathrm{NaCl}$ on resistance to methicillin

Oxford staphylococcus

\begin{tabular}{|c|c|c|c|c|c|c|c|c|c|}
\hline \multirow{3}{*}{$\begin{array}{l}\text { Concentration } \\
\text { of methicillin } \\
(\mu \mathrm{g} \text { per } \mathrm{ml})\end{array}$} & \multirow{3}{*}{$\begin{array}{l}5 \text { per cent. } \\
\mathrm{NaCl} \\
\text { added }\end{array}$} & \multicolumn{8}{|c|}{$\begin{array}{l}\text { Colony growth, on agar containing this concentration of methicillin: } \\
\text { of } 0.02 \mathrm{ml} \text { culture }\end{array}$} \\
\hline & & \multirow{2}{*}{ undiluted } & \multicolumn{7}{|c|}{ diluted } \\
\hline & & & $10^{-1}$ & $10^{-2}$ & $10^{-3}$ & $10^{-4}$ & $10^{-5}$ & $10^{-6}$ & $10^{-7}$ \\
\hline $\begin{array}{l}0 \\
0 \\
0.625 \\
0.625 \\
1.25 \\
1.25 \\
2.5 \\
2.5\end{array}$ & $\begin{array}{l}\frac{ \pm}{+} \\
\frac{+}{+} \\
\pm \\
\pm \\
+\end{array}$ & $\begin{array}{r}\ldots \\
\ldots \\
\dddot{C}^{*} \\
50 \\
150 \\
24 \\
5 \\
0\end{array}$ & $\begin{array}{r}\ldots \\
\ldots \\
\mathrm{C} \\
18 \\
75 \\
13 \\
0 \\
0\end{array}$ & $\begin{array}{r}\ldots \\
\ldots \\
\mathrm{SC} \\
3 \\
30 \\
2 \\
0 \\
0\end{array}$ & $\begin{array}{r}\ldots \\
\ldots \\
\text { SC } \\
0 \\
4 \\
0 \\
0 \\
0\end{array}$ & $\begin{array}{r}\ldots \\
\dddot{\mathrm{SC}} \\
0 \\
1 \\
0 \\
0 \\
0\end{array}$ & $\begin{array}{r}\ldots \\
\dddot{75} \\
0 \\
0 \\
0 \\
0 \\
0\end{array}$ & $\begin{array}{r}55 \\
57 \\
20 \\
0 \\
0 \\
0 \\
0 \\
0\end{array}$ & $\begin{array}{l}5 \\
4 \\
4 \\
0 \\
0 \\
0 \\
0 \\
0\end{array}$ \\
\hline
\end{tabular}

$* \mathrm{C}=$ Conffuent growth; $\mathrm{SC}=$ numerous colonies; numbers $=$ number of colonies.

$0.02 \mathrm{ml}$ of the appropriate dilution of culture (grown for $6 \mathrm{hr}$ at $35^{\circ} \mathrm{C}$ in $\mathrm{CY}$-medium) was dropped on to the surface of $\mathrm{CY}$-agar containing the methicillin. After $1 \mathrm{hr}$ at room temperature the plate was transferred to $37^{\circ} \mathrm{C}$ and incubated for $48 \mathrm{hr}$ and then the results were recorded.

(b) The second part was incubated at $35^{\circ} \mathrm{C}$ for $3 \frac{1}{2} \mathrm{hr}$ and then spread on $\mathrm{CY}$-agar with added methicillin at $5 \mu \mathrm{g}$ per $\mathrm{ml}$ or $10 \mu \mathrm{g}$ per $\mathrm{ml}$.

(c) To the third part, methicillin was added to a final concentration of $1.25 \mu \mathrm{g}$ per $\mathrm{ml}$, followed after 3 hours' incubation at $35^{\circ} \mathrm{C}$ with a further addition of methicillin to a final concentration of $2.5 \mu \mathrm{g}$ methicillin per $\mathrm{ml}$. The culture was incubated for $16 \mathrm{hr}$ further and then spread on CY-agar containing 5 or $10 \mu \mathrm{g}$ methicillin per $\mathrm{ml}$.

Colonies appeared on the lower concentration of methicillin after $48 \mathrm{hr}$ at $37^{\circ} \mathrm{C}$, but equivalent numbers of colonies also appeared on control plates where the recipient was treated in exactly the same way apart from the presence of any bacteriophage. Subculture of colonies from either the control or the culture which had been mixed with phage produced cultures with no significantly raised level of resistance to methicillin.

The experiment was repeated with phage 53 grown on a culture freshly isolated from agar containing $500 \mu \mathrm{g}$ methicillin per $\mathrm{ml}$, but no evidence of transduction was obtained. 
The isolation of no. $13136 \mathrm{~N} / \mathrm{S}$, which was homogeneously resistant to $500 \mu \mathrm{g}$ methicillin per ml, permitted repetition of the experiment under more advantageous conditions. Phage 53 was propagated on this strain and used in transduction experiments with three recipients: no. 524SC N, no. $13371 \mathrm{~N}$ (a multiple-resistant strain sensitive to phage 53), and no. 13136N. Multiplicity of infection of $0.01,0.2$ and 0.9 were used for each recipient and transductants selected on 5, 10 and $50 \mu \mathrm{g}$ methicillin per $\mathrm{ml}$, after allowing time for expression

IV

methicillin-sensitive and methicillin-resistant cultures at $48 \mathrm{hr}$

Strain $13136 N$

\begin{tabular}{|c|c|c|c|c|c|c|c|c|c|}
\hline \multirow{3}{*}{$\begin{array}{l}\text { Concentration } \\
\text { of methicillin } \\
(\mu \mathrm{g} \text { per } \mathrm{ml})\end{array}$} & \multirow{3}{*}{$\begin{array}{l}5 \text { per cent. } \\
\mathrm{NaCl} \\
\text { added }\end{array}$} & \multicolumn{8}{|c|}{$\begin{array}{l}\text { Colony growth, on agar containing this concentration of methicillin, } \\
\text { of } 0.02 \mathrm{ml} \text { culture }\end{array}$} \\
\hline & & \multirow{2}{*}{ undiluted } & \multicolumn{7}{|c|}{ diluted } \\
\hline & & & $10^{-1}$ & $10^{-2}$ & $10^{-3}$ & $10^{-4}$ & $10^{-5}$ & $10^{-6}$ & $10^{-7}$ \\
\hline 0 & + & $\ldots$ & $\ldots$ & $\ldots$ & $\ldots$ & $\ldots$ & $\ldots$ & 32 & 3 \\
\hline 0 & - & $\cdots$ & $\ldots$ & $\ldots$ & $\ldots$ & $\cdots$ & $\ldots$ & 37 & 3 \\
\hline 10 & + & $\dddot{\mathrm{C}}$ & $\dddot{\mathrm{C}}$ & $\dddot{\mathrm{C}}$ & $\dddot{\mathrm{C}}$ & $\ddot{\mathrm{SC}}$ & $\dddot{\text { SC }}$ & 49 & 4 \\
\hline 10 & - & $\mathrm{C}$ & C & $\mathrm{SC}$ & 7 & 4 & 0 & 0 & 0 \\
\hline 40 & + & C & C & $\mathrm{C}$ & C & $\mathrm{SC}$ & SC & 54 & 3 \\
\hline 40 & - & $\mathrm{C}$ & 75 & 16 & 6 & 3 & 0 & 0 & 0 \\
\hline 160 & + & $\mathrm{C}$ & 150 & 32 & 6 & 0 & 0 & 0 & 0 \\
\hline 160 & - & C & 70 & 25 & 6 & 1 & 0 & 0 & 0 \\
\hline 640 & + & $\mathrm{C}$ & SC & 28 & 1 & 0 & 0 & 0 & 0 \\
\hline 640 & - & 5 & 0 & 1 & 0 & 0 & 0 & 0 & 0 \\
\hline
\end{tabular}

of any transductants in the same way as in the previous experiment. In no case were there more colonies on any plate than there were on a phage-free control. Thus all attempts to transduce methicillin resistance failed.

\section{Effect of sodium chloride on methicillin resistance}

It has been shown that 5 per cent. (w/v) sodium chloride increases the phenotypic resistance of methicillin-resistant cultures (Barber, 1964). Seligman $(1966 b)$ considered that this effect is on the sensitive majority of the population, whereas the minority of highly resistant cells is inhibited by the salt. If this effect is due, entirely or in part, to osmotic protection from lysis, the methicillinresistance of sensitive cultures should also be increased.

Dilutions of cultures of no. $13136 \mathrm{~N}$ and of the Oxford staphylococcus were placed on the surface of agar containing different concentrations of methicillin with and without added 5 per cent. (w/v) NaCl. The results (table IV) indicate that for the Oxford strain there is a very marked difference at $0.625 \mu \mathrm{g}$ methicillin 
per $\mathrm{ml}$, in that all the cells form colonies in the presence of the $\mathrm{NaCl}$, but only about 1 in 100,000 forms a colony in its absence. At $1.25 \mu \mathrm{g}$ methicillin per $\mathrm{ml}$ a few cells still form a colony in the absence of salt, but this number is increased five- to ten-fold in the presence of salt. These results are interpreted as showing that $\mathrm{NaCl}$ induces a small increase in the resistance of culture, and that this increase applies both to the more and to the less sensitive organisms in the population.

The slight heterogeneity of resistance of the Oxford staphylococcus illustrated in table IV is not demonstrated in all experiments and on occasions the

TABLE V

Effect of temperature on the minimum inhibitory concentration of methicillin determined by a tube dilution test and read at $48 \mathrm{hr}$

\begin{tabular}{|c|c|c|c|c|}
\hline \multirow{2}{*}{ Strain no. } & \multicolumn{4}{|c|}{$\begin{array}{l}\text { Minimal inhibitory concentration of } \\
\text { methicillin }(\mu \mathrm{g} \text { per } \mathrm{ml}) \text { at }\end{array}$} \\
\hline & $22^{\circ} \mathrm{C}$ & $30^{\circ} \mathrm{C}$ & $37^{\circ} \mathrm{C}$ & $43^{\circ} \mathrm{C}$ \\
\hline $\begin{array}{l}\text { Methicillin-resistant } \\
9204 \\
13136 \mathrm{~N}\end{array}$ & $\begin{array}{r}>2000 \\
2000\end{array}$ & $\begin{array}{r}1000 \\
500\end{array}$ & $\begin{array}{l}250 \\
125\end{array}$ & $\begin{array}{r}150 \\
25\end{array}$ \\
\hline $\begin{array}{l}\text { Methicillin-sensitive } \\
524 \mathrm{SC} \mathrm{N}\end{array}$ & $3 \cdot 12$ & $6 \cdot 25$ & $6 \cdot 25$ & $6 \cdot 25$ \\
\hline
\end{tabular}

Inoculum of $c .5 \times 10^{6}$ organisms in a volume of $5.0 \mathrm{ml}$.

heterogeneity was considerably greater. Since the results are not completely reproducible it is difficult to give precise results. Whether or not heterogeneity is present probably depends on a variety of factors including the stage of growth of the inoculum, the dryness of the agar plates, the time the drop of culture is allowed to dry before being placed in an incubator and the stacking of the plates in the incubator. The heterogeneity of this and other methicillinsensitive strains is quantitatively different from the heterogeneity displayed by methicillin-resistant strains. Many of the colonies of the Oxford staphylococcus growing on CY-agar containing $1.25 \mu \mathrm{g}$ methicillin per $\mathrm{ml}$ with added salt, have the appearance of L-form colonies (Kagan, Martin and Stewart, 1964). The colonies are opaque but covered with a translucent material, and when the colony is scraped off it can be seen to have burrowed into the agar in a way typical of L-forms. Under the microscope the cells appear as L-form cells. No L-form colonies were ever seen on media not containing salt, but the difference between the number of colonies at $1.25 \mu \mathrm{g}$ methicillin per ml with salt as compared to the same concentration without salt is accounted for by the L-form colonies.

The resistance of the sensitive majority of no. $13136 \mathrm{~N}$ is increased markedly by 5 per cent $\mathrm{w} / \mathrm{v} \mathrm{NaCl}$. Thus all the cells give rise to colonies at $40 \mu \mathrm{g}$ methicillin per $\mathrm{ml}$ in the presence of salt, but only 1 in 1000 produce colonies 
at $10 \mu \mathrm{g}$ methicillin per $\mathrm{ml}$ in the absence of salt. A greater number of the more resistant majority are able to produce colonies on $640 \mu \mathrm{g}$ methicillin per $\mathrm{ml}$ in the presence of salt than in its absence. It is not possible to decide whether or not the resistance of the sensitive majority is increased to a greater extent than the resistance of the resistant minority.

The effect is not specific for $\mathrm{NaCl}$, since qualitatively similar results were obtained with $\left(\mathrm{NH}_{4}\right)_{2} \mathrm{SO}_{4}$ or $\mathrm{NaNO}_{3}$, or $\mathrm{KCl}$ in place of $\mathrm{NaCl}$. Reduction of

TABLE VI

Effect of temperature on number of colonies surviving on $20 \mu \mathrm{g}$ methicillin per $\mathrm{ml}$ at $48 \mathrm{hr}$ at various temperatures

\begin{tabular}{|c|c|c|c|c|c|c|c|c|}
\hline \multirow{3}{*}{ Temperature } & \multicolumn{8}{|c|}{$\begin{array}{c}\text { Colony growth, on agar containing } 20 \mu \mathrm{g} \text { methicillin per ml, of } \\
\qquad 0.02 \mathrm{ml} \text { of culture of no. } 13136 \mathrm{~N}\end{array}$} \\
\hline & \multirow{2}{*}{ undiluted } & \multicolumn{7}{|c|}{ diluted } \\
\hline & & $10^{-1}$ & $10^{-2}$ & $10^{-3}$ & $10^{-4}$ & $10^{-5}$ & $10^{-6}$ & $10^{-7}$ \\
\hline $22^{\circ} \mathrm{C}$ & $\mathrm{C}^{*}$ & $\mathrm{C}$ & $\mathrm{SC}$ & 250 & 30 & 2 & 0 & 0 \\
\hline $30^{\circ} \mathrm{C}$ & $\mathrm{C}$ & $\mathrm{C}$ & $\mathrm{SC}$ & 200 & 31 & 7 & 0 & 0 \\
\hline $37^{\circ} \mathrm{C}$ & $\mathrm{C}$ & $\mathrm{C}$ & $\mathrm{SC}$ & 50 & 3 & 0 & 0 & 0 \\
\hline $43^{\circ} \mathrm{C}$ & $\mathrm{C}$ & SC & 6 & 0 & 0 & 0 & 0 & 0 \\
\hline
\end{tabular}

$\mathrm{C}=$ Confluent growth; $\mathrm{SC}=$ numerous small colonies; numbers $=$ number of colonies.

$0.02 \mathrm{ml}$ of a CY-culture of no. $13136 \mathrm{~N}$ (containing $2 \times 10^{9}$ organisms per ml) placed on agar containing $20 \mu \mathrm{g}$ methicillin per ml.

the concentration of agar did not, in our hands, give an increased phenotypic resistance, in contrast with the results obtained by Barber.

\section{Effect of temperature on resistance to methicillin}

The minimal inhibitory concentrations (MIC) of methicillin for two methicillin-resistant cultures and one methicillin-sensitive culture were determined by a tube dilution method at four different temperatures (table V). There is a gradation of MIC for both methicillin-resistant cultures with very high values at the lowest temperature. For the single methicillin-sensitive strain (no. 524SC N) there is little effect of temperature on the MIC. Similar results were obtained when colony counts at different concentrations of methicillin were determined after incubation of the plates at the different temperatures (table VI), except that the results at $22^{\circ} \mathrm{C}$ and $30^{\circ} \mathrm{C}$ were the same, apart from the larger size of colonies at $30^{\circ} \mathrm{C}$.

The results on MIC are in agreement with those obtained by Annear (1968). 


\section{Comparison of mucopeptide of methicillin-resistant and methicillin-sensitive cells}

Cells might be resistant to methicillin because they have a higher proportion of their cell mass as cell wall material, so that inhibition of synthesis of cell wall

TABLE VII

Weight of mucopeptide as percentage of dry wt of whole cells

\begin{tabular}{|c|c|c|c|c|}
\hline \multirow{3}{*}{ Strain no. } & & \multicolumn{3}{|c|}{ Percentage dry wt of cells grown in } \\
\hline & & \multicolumn{2}{|c|}{ absence of methicillin } & \multirow{2}{*}{ presence of methicillin } \\
\hline & & Batch A & Batch B & \\
\hline $\begin{array}{l}\text { Methicillin-sensitive } \\
\text { Oxford } \\
\text { 524SC N }\end{array}$ & : & $\begin{array}{l}25 \cdot 6 \\
21 \cdot 0\end{array}$ & $\begin{array}{l}20 \cdot 8 \\
26 \cdot 3\end{array}$ & $\begin{array}{l}13.9(1.25 \mu \mathrm{g} \text { methicillin per } \mathrm{ml}) \\
14.3(2.5 \mu \mathrm{g} \text { methicillin per } \mathrm{ml})\end{array}$ \\
\hline $\begin{array}{l}\text { Methicillin-resistant } \\
13136 \mathrm{~N} / \mathrm{S} \\
13136 \mathrm{~N} / \mathrm{S}\end{array}$ & $\dot{.}$ & $\begin{array}{l}20 \cdot 0 \\
22 \cdot 0\end{array}$ & $\begin{array}{l}19 \cdot 0 \\
19 \cdot 2\end{array}$ & $\begin{array}{l}13 \cdot 7(50 \mu \mathrm{g} \text { methicillin per } \mathrm{ml}) \\
16 \cdot 2(50 \mu \mathrm{g} \text { methicillin per } \mathrm{ml})\end{array}$ \\
\hline
\end{tabular}

Mucopeptide was prepared from a known amount of cells as described in Methods and weighed to constant wt.

TABLE VIII

Molar ratios of amino acids in cell walls

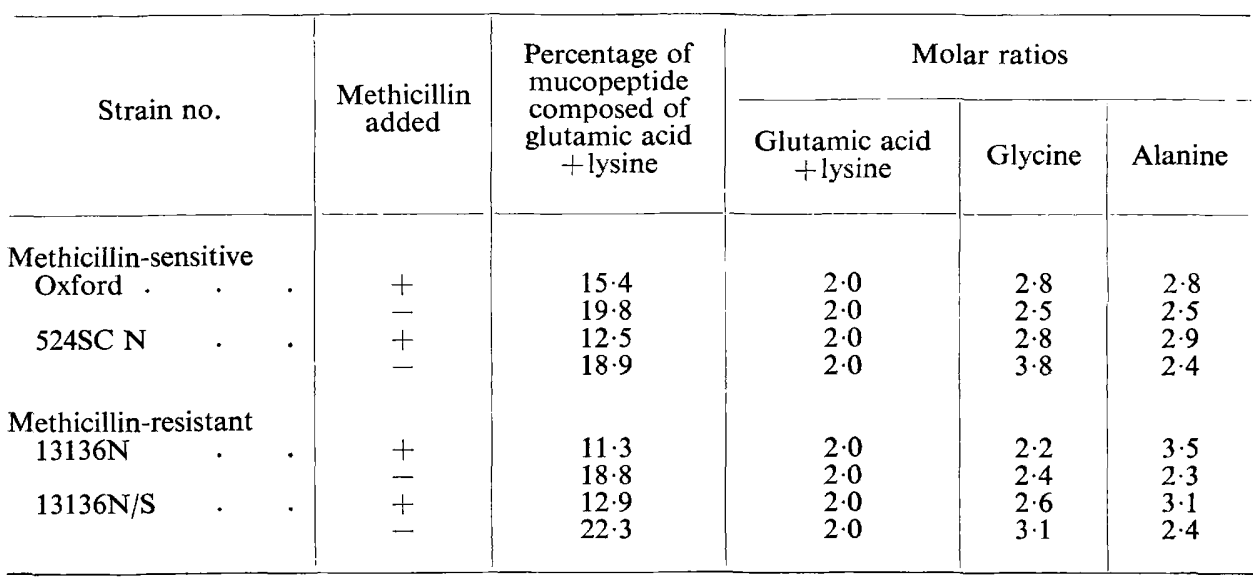

Hydrolysed mucopeptide was chromatographed on paper with butanol:acetic acid:water $(6: 4: 3$ by vol.) and sprayed with ninhydrin; the ninhydrin-positive areas were eluted and the amount of amino acids estimated spectrophotometrically.

material would have a relatively small effect on the viability of the cells. To test this, the quantity of mucopeptide present in a known weight of bacteria was determined (table VII). The figures represent the mean of three determinations for each batch of cells. Individual determinations varied by as much 
as 20 per cent. by this method. Nevertheless, no greater proportion of cell wall material is present either in the heterogeneous resistant no. $13136 \mathrm{~N}$ or the highly resistant homogeneous mutant (no. $13136 \mathrm{~N} / \mathrm{S}$ ) derived from it, than in either the Oxford staphylococcus or no. 524SC N. Growth in the presence of concentrations of methicillin that lengthened the mean generation time by approximately 20 per cent. decreased the proportion of mucopeptide in every case.

Although there is no evidence for a difference in the proportion of the cell mass that is mucopeptide, the composition of the mucopeptide might be different in methicillin-resistant and methicillin-sensitive strains. The composition of mucopeptide in the different strains was therefore investigated (table VIII). There is no major difference in the amino acid composition, and no significant change in this composition when the organisms had been grown in the presence of slightly inhibitory concentrations of methicillin.

The proportion of the mucopeptide formed by glucosamine and muramic acid and the ratio of these two compounds was not significantly different in no. $13136 \mathrm{~N}$ compared with no. $524 \mathrm{SC} \mathrm{N}$.

\section{Discussion}

The prediction that Staphylococcus aureus strains with an increased ability to hydrolyse methicillin might make their appearance in hospital populations has not yet been fulfilled. Among the large number of methicillin-resistant strains examined in this survey, I found no evidence of a modified penicillinase molecule with the properties of a "methicillinase". This may be explained in one of several ways. First, the requisite modification in the enzyme may require the substitution of several amino acids in a series of changes. The "intermediate" penicillinase molecules might have no activity on benzylpenicillin, so that mutants at this stage might be at a significant disadvantage in the hospital environment, and might not survive there long enough to undergo the subsequent mutations. Secondly, the hospital environment is perhaps not sufficiently competitive for a methicillinase-producing mutant to possess a significant advantage over a "conventional" methicillin-resistant strain. Thirdly, the time scale of the survey may have been too short. Fourthly, the selection pressure for the use of methicillin in hospital may not have been strong enough to select; that is to say not enough patients have been treated at one time in any place. Conventional methicillin-resistant strains are not yet very common in Britain and their spread, such as it is, may be due to the advantages conferred by their intrinsic resistance to other penicillins that have been more widely used.

All naturally occurring methicillin-resistant cultures of $S$. aureus that have been studied exhibit a population heterogeneity in their resistance to methicillin. Is this heterogeneity a result of multistep (or polygenic) resistance to methicillin in which the steps are additive, so that many different degrees of resistance to methicillin are demonstrable within a population; or is resistance a phenotypic phenomenon in which, on division of the bacterium the distribution of relatively long-lived molecules conferring resistance is unequal? The failure to transduce 
methicillin resistance does not preclude either possibility; a polygenic resistance system is unlikely to be transduced in toto and a phenotypic phenomenon would not be transducible. The rapid rate of reversion to methicillin sensitivity (table III) implies that, if the idea of polygenic resistance is accepted, it is necessary to postulate a mutator gene that increases the rate of mutation, at least of the genes concerned with resistance, as suggested by Kayser (1965). No. $13136 \mathrm{~N} / \mathrm{S}$ could be interpreted as a mutant that has lost its mutator gene and is " fixed " in a state of high resistance, with reversion to sensitivity occurring at a much lower frequency than in no. $13136 \mathrm{~N}$. If this is true, transduction from this stabilised donor might have been expected. No such transduction was found even when low concentrations of methicillin were used for selection of transductants.

An explanation of the results on the basis of the theory of clonal variation can also be proposed (Yudkin, 1953). Let us assume that the cells are resistant to methicillin because the control system for synthesis of some cell-wall component is faulty, with the result that an excess of that component is produced. If the excess is unevenly distributed, so that on division the two daughter cells differ in the amount of this component, they would differ in their resistance to methicillin, and at some concentration of antibiotic one would be killed and the other would survive. A population that behaved in a similar way to a methicillin-resistant culture would result if there were large numbers of molecules of the excess component. The observed slow growth rate in the presence of methicillin, and the rapid reversion to the sensitive state in the absence of methicillin would be explained if it were assumed that the energy necessary for the synthesis of the excess wall component reduces the growth rate of the highly resistant cells. Dilution of the component on division might explain the anomalous result in table III, where the highly resistant cells present at the beginning have not survived the subculturing and certainly have not multiplied. Neither hypothesis is very satisfactory.

The relation between growth rate and resistance to methicillin is complex and will not be easy to explain until much more of the mechanism of resistance is understood. At low temperature, the rate of synthesis of cell wall may be higher relative to the other syntheses, but at high temperature the cell may be channelling a greater proportion of its energy into the production of macromolecules other than cell wall, so that the cell is more susceptible to inhibitors of cell-wall synthesis. The effect of $\mathrm{NaCl}$ and other salts may be two-fold, in that they both provide a higher osmotic pressure and so prevent damage to weakening cells, and by some other process reduce the growth rate. No. $13136 \mathrm{~N} / \mathrm{S}$ confuses these findings since, though it is resistant and grows slowly, a derived variant is as resistant but grows rapidly.

If intrinsic resistance is due to a quantitative or qualitative change in the cell wall it might be possible to detect such a change. Rogers and Jeljaszewicz (1961) investigated the composition of the cell wall of staphylococci made resistant to penicillin and compared their results with the cell wall of the sensitive parents. They detected no gross difference. The results reported in this paper also show no gross difference even with the no. $13136 \mathrm{~N} / \mathrm{S}$ strain so 
that one must conclude that if differences exist they are smaller than the present insensitive methods can detect.

\section{SUMMARY}

The hydrolysis of methicillin by the penicillinase produced by 108 epidemiologically distinct methicillin-resistant strains of Staphylococcus aureus has been investigated. In no case is there evidence for a variant enzyme with increased efficiency of hydrolysis of methicillin. Cultures of penicillinasenegative variants of methicillin-resistant strains are heterogeneous in their resistance to methicillin. In all but one case, organisms resistant to a high concentration of methicillin revert to a heterogeneous resistance pattern on subculture in the absence of methicillin. Methicillin-resistant strains do not grow slowly in the absence of methicillin, but are more resistant to methicillin when grown at low temperature or when grown in the presence of sodium chloride. The mucopeptide of methicillin-resistant cells does not differ from that of methicillin-sensitive cells either in amount or composition. Possible mechanisms of methicillin resistance are discussed.

I wish to thank Professor M. R. Pollock and Dr M. H. Richmond for encouragement and many helpful discussions, and Dr M. T. Parker and his colleagues at this laboratory for their help in examining strains and continuing advice and interest in the work. Mr D. J. McGillicuddy and Mrs A. J. Raine gave expert technical assistance. I am indebted to Beecham Research Laboratories for a generous gift of methicillin.

\section{REFERENCES}

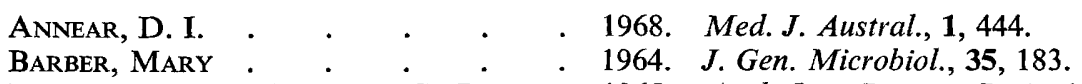

Baudens, J. G., Gerbaud, G. R., and 1965. Annls Inst. Pasteur, Paris, 109, 372.

ChaBbert, Y. A.

Chabbert, Y. A., ANd Baudens, J. G. . 1962. Ibid., 103, 222.

DYKe, K. G. H. . . . . . . 1967. Biochem. J., 103, 641.

Dyke, K. G. H., Jevons, M. Patricia, 1966. Lancet, 1, 835. AND PARKeR, M. T.

ERIKSEN, K. R., AND ERICHSEN, INGRID

JeVons, M. Patricia . $\cdot$. .

Jevons, M. Patricia, Coe, A. W., AND PARKer, M. T.

KaGAN, B. M., MARTin, E. R., AND 1964. Nature, Lond., 203, 1031.

STEWART, G. T.

KAYSER, F-H.

KNOX, R.

1964. Acta path. microbiol. scand., 62, 255.

1961. Br. Med. J., 1, 124.

1963. Lancet, 1, 904.

MANDElstam, J., AND Rogers, H. J.

Novick, R. P.

1965. Path. Microbiol., 28, 985.

1961. Br. Med.J., 1, 126.

1959. Biochem. J., 72, 654.

1962. Ibid., 83, 229.

1963. J. Gen. Microbiol., 33, 121.

PARK, J. T., AND HANCOCK, R. $\quad$. $\quad . \quad 1960$. Ibid., 22, 249.

Parker, M. T., and Jevons, M. Patricia 1964. Post-grad. Med. J., 40, Suppl., p. 170.

Perkins, H. R., ANd Rogers, H. J. . 1959. Biochem. J., 72, 647.

Perret, C. J. $\quad$. $\quad$. $\quad$. $\quad$. 1954. Nature, Lond., 174, 1012.

Pollock, M. R. . $\quad . \quad \quad . \quad \quad . \quad$. 1962. In Resistance of bacteria to the penicillins, ed. by A. V. S. de Reuck and M. P. Cameron, London, p. 67. 
RICHMOND, M. H. _ . $\quad$. $\quad$. 1965. Biochem. J., 94, 584.

Richmond, M. H., PARKer, M. T., 1964. Lancet, 1, 293. Jevons, M. Patricia, and John, M.

ROGERS, H. J.

Rogers, H. J., AND Jeljaszewicz, J.

Rolinson, G. N. . . . . . 1961. Br. Med. J., 1, 125.

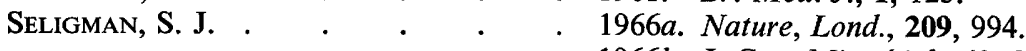

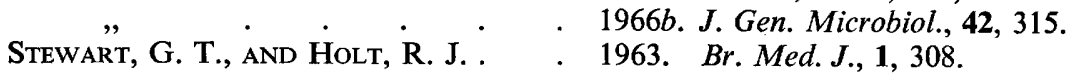

Swanstrom, M., and Adams, M. H. - 1951. Proc. Soc. Exp. Biol. Med., 78, 372.

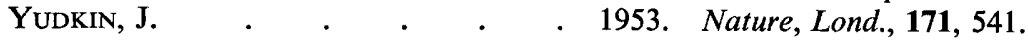

